\title{
Parallel structures for disaster risk reduction and climate change adaptation in Southern Africa
}

\begin{tabular}{|c|c|}
\hline \multicolumn{2}{|c|}{$\begin{array}{l}\text { Marcus Abrahamsson }{ }^{1} \\
\text { Magnus Hagelsteen }^{1}\end{array}$} \\
\hline \multicolumn{2}{|c|}{$\begin{array}{l}{ }^{1} \text { Training Regions Research } \\
\text { Centre, Lund University } \\
\text { Centre for Risk Assessment } \\
\text { and Management, Sweden }\end{array}$} \\
\hline \multicolumn{2}{|c|}{$\begin{array}{l}\text { Correspondence to: } \\
\text { Per Becker }\end{array}$} \\
\hline \multicolumn{2}{|c|}{$\begin{array}{l}\text { Email: } \\
\text { per.becker@lucram.lu.se }\end{array}$} \\
\hline \multicolumn{2}{|c|}{$\begin{array}{l}\text { Postal address: } \\
\text { LUCRAM, Lund Univers } \\
\text { Box 118, } 22100 \text { LUND, } \\
\text { Sweden }\end{array}$} \\
\hline \multicolumn{2}{|c|}{$\begin{array}{l}\text { Received: } 17 \text { June } 2012 \\
\text { Accepted: } 12 \text { Oct. } 2012 \\
\text { Published: } 23 \text { Jan. } 2013\end{array}$} \\
\hline \multicolumn{2}{|c|}{$\begin{array}{l}\text { How to cite this article: } \\
\text { Becker, P., Abrahamsson, } \\
\text { M. \& Hagelsteen, M., 2013, } \\
\text { 'Parallel structures for } \\
\text { disaster risk reduction and } \\
\text { climate change adaptation } \\
\text { in Southern Africa', Jàmbá: } \\
\text { Journal of Disaster Risk } \\
\text { Studies 5(2), Art. \#68, } \\
5 \text { pages. http://dx.doi. } \\
\text { org/10.4102/jamba.v5i2.68 }\end{array}$} \\
\hline \multicolumn{2}{|c|}{$\begin{array}{l}\text { Note: } \\
\text { 1st Biennial Conference, } \\
\text { Southern African Society for } \\
\text { Disaster Reduction (SASDiR), } \\
09 \text { to } 11 \text { October 2012, } \\
\text { Potchefstroom, South Africa. }\end{array}$} \\
\hline \multicolumn{2}{|c|}{$\begin{array}{l}\text { Copyright: } \\
\text { (C) 2013. The Authors } \\
\text { Licensee: AOSIS } \\
\text { OpenJournals. This w } \\
\text { is licensed under the } \\
\text { Creative Commons } \\
\text { Attribution License. }\end{array}$} \\
\hline Read online: & \\
\hline 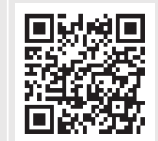 & $\begin{array}{l}\text { Scan this QR } \\
\text { code with your } \\
\text { smart phone or } \\
\text { mobile device } \\
\text { to read online. }\end{array}$ \\
\hline
\end{tabular}

During the last decade, the interest of the international community in the concepts of disaster risk reduction and climate change adaptation has been growing immensely. Even though an increasing number of scholars seem to view these concepts as two sides of the same coin (at least when not considering the potentially positive effects of climate change), in practice the two concepts have developed in parallel rather than in an integrated manner when it comes to policy, rhetoric and funding opportunities amongst international organisations and donors. This study investigates the extent of the creation of parallel structures for disaster risk reduction and climate change adaptation in the Southern African Development Community (SADC) region. The chosen methodology for the study is a comparative case study and the data are collected through focus groups and content analysis of documentary sources, as well as interviews with key informants. The results indicate that parallel structures for disaster risk reduction and climate change adaptation have been established in all but one of the studied countries. The qualitative interviews performed in some of the countries indicate that stakeholders in disaster risk reduction view this duplication of structures as unfortunate, inefficient and a fertile setup for conflict over resources for the implementation of similar activities. Additional research is called for in order to study the concrete effects of having these parallel structures as a foundation for advocacy for more efficient future disaster risk reduction and climate change adaptation.

\section{Introduction}

The last decade has seen a sharp increase in the international community's interest in disaster risk reduction (DRR). During the same period, climate change adaptation (CCA) has also risen on the agenda (Schipper 2009:17-18), spurring an academic debate over the extent to which the two concepts overlap (Kelman \& Gaillard 2008; Mercer 2010; Mitchell \& Van Aalst 2008; Schipper 2009; Shea 2003). Although some definitions of CCA also include the potential benefits of climate change (e.g. IPCC 2007), adapting to the potential negative impacts of climate change is by far the main focus (Satterthwaite et al. 2009), making it more or less a part of DRR in practice (Mitchell \& van Aalst 2008:4; Mercer 2010). However, the practice of separating the two with regard to policy, rhetoric and funding opportunities among international organisations and donors may encourage the establishment of parallel structures for DRR and CCA in developing countries.

The purpose of this study is to investigate the extent of the creation of parallel structures for DRR and CCA in the Southern African Development Community (SADC) region. In order to meet that purpose, the study intends to answer the following research question: To what extent have parallel structures been established for disaster risk reduction and climate change adaptation in Botswana, Lesotho, Malawi, Mozambique, Seychelles, Swaziland, Tanzania, Zambia and Zimbabwe?

\section{Theoretical framework}

Proactive activities to reduce disaster risk are nothing new, and they have been called a number of different things over the years. Prevention and or mitigation and preparedness were already part of early definitions of emergency or disaster management, together with response and recovery. However, it has been noted that the most common strategy for disaster management over the years has been to respond in a reactive manner when disaster has already struck (Jeggle 2001). As an attempt to increase the focus on proactive activities, the ideas of disaster reduction (IDNDR 1994; Jeggle 2001) and then disaster risk reduction (Vermaak \& Van Niekerk 2004; White et al. 2004; Twigg 2004) were invented.

Although these new concepts initially attracted limited attention amongst most stakeholders in the international community, the 2004 Indian Ocean tsunami provided significant political momentum at the World Conference on Disaster Reduction held in Kobe just a month later. The 
final product of this conference was the Hyogo Framework for Action, a framework with the purpose to facilitate the 'substantial reduction of disaster losses, in lives and in the social, economic and environmental assets of communities and countries' (ISDR 2005).

The Hyogo Framework for Action focuses on disaster risk reduction and specifies five priority areas for action (ISDR 2005:5-13). When analysing the framework, including the lessons learnt from the preceding Yokohama Strategy, two dimensions emerge. Firstly, it specifies that DRR in general comprises risk assessment (priority area $2 /$ lesson b), prevention and or mitigation (priority area 4 /lesson $\mathrm{d}$ ) and preparedness for response and recovery (priority area 5/lesson e). Secondly, it emphasises that effective implementation of DRR requires sound legal and institutional frameworks (priority area $1 /$ lesson a), close collaboration between organisations (priority area $1 /$ lesson a), well-functioning organisations (priority areas 1 and 3/lessons a and c) and sufficient human and material resources (priority areas 1 and 3/lessons a and c).

There are many definitions of DRR to be found in literature. However, one of the more influential definitions states that disaster risk reduction is:

'[the] conceptual framework of elements considered with the possibilities to minimize vulnerabilities and disaster risks throughout a society, to avoid (prevention) or to limit (mitigation and preparedness) the adverse impacts of hazards, within the broad context of sustainable development'. (ISDR 2004:17)

This definition was initially endorsed and advocated by the United Nations International Strategy for Disaster Reduction (UNISDR), which for some reason later changed it to:

'[the] concept and practice of reducing disaster risks through systematic efforts to analyse and manage the causal factors of disasters, including through reduced exposure to hazards, lessened vulnerability of people and property, wise management of land and the environment, and improved preparedness for adverse events'. (UNISDR 2009:10-11)

Although the greenhouse effect was discovered more than a century ago (Arrhenius 1896), it was not until the first Conference of the Parties (COP 1) in 1995 that the concept of climate change adaptation gained momentum. Time-wise, this is much in line with the history of DRR. As the interest for climate change adaptation grew, a range of definitions appeared, some of which included both the potentially positive and negative effects of climate change (e.g. IPCC 2007) whilst others restricted their definitions to include only the negative effects (e.g. Satterthwaite et al. 2009).

The Intergovernmental Panel on Climate Change (IPCC) defines adaptation as '[a]djustment in natural or human systems in response to actual or expected climatic stimuli or their effects, which moderates harm or exploits beneficial opportunities' (IPCC 2007:869). This is one of the most influential definitions of climate change adaptation and includes some interesting aspects. Firstly, it highlights the importance of acting today to adapt our society to anticipated future change. Secondly, it states that the purpose of such adjustments is to either reduce the adverse impacts or take advantage of the potential benefits of a changing climate.

Looking at policy, rhetoric, funding opportunities, etcetera, it is clear that the interest of the world is firmly set on adapting to the potential negative impacts of climate change, which serves to explain the proliferation of definitions that focus entirely on that subject. One influential example of this defines climate change adaptation as the '[a]ctions to reduce the vulnerability of a system (e.g. a city), population (e.g. a vulnerable population in a city) or individual to the adverse impacts of anticipated climate change due to emission of greenhouse gases' (Satterthwaite et al. 2009:9). This definition is particularly interesting as it is linked to descriptions of categories of actual adaptation activities. These categories are protection (disaster avoidance), preparedness, response and rebuilding (Satterthwaite et al. 2009:36) and are described in an identical manner to the prevention and or mitigation, preparedness, response and recovery of traditional definitions of disaster management.

Today CCA is on everybody's lips, but considering the current focus on adapting to the potential negative impacts of climate change, it has been suggested that it be linked to DRR (Mercer 2010; Mitchell \& Van Aalst 2008; Schipper 2009). This becomes particularly pertinent in developing countries that cannot afford parallel structures, but are attempting to achieve similar objectives. Such structures may not only compete for the same resources, but may even impede each other's work if they end up sending mixed messages to the policy-makers and budget-holders.

\section{Methodology}

The outline and contemporary context of the research question makes comparative case study research a particularly suitable methodology (Yin 1994:4-9). Case studies are often criticised for allowing bias to influence their conclusions (Yin 1994:9-10). This is not a weakness of case study research as such, as bias must be properly treated, regardless of methodology. Another frequent critique is that case studies offer little basis for generalisation (Flyvbjerg 2001:66; Yin 1994:10). This holds for statistical generalisations, but not for analytical generalisations, for which case studies have proven useful (Flyvbjerg 2001:73-77). Knowledge developed in one case can however not be generalised 'through abstraction and loss of history and context', but may be transferred to other situations through 'conscious reflection on similarities and differences between contextual features and historical factors' (Greenwood \& Levin 2007:70).

A combination of opportunity and the level of active involvement in SADC of the individual member states determined the selection of the cases for this study. The 
authors' involvement in capacity assessments for DRR and CCA in Botswana and Tanzania, as well as fact-finding journeys to Zambia and Zimbabwe, provided detailed data. Lesotho, Malawi, Mozambique, Seychelles and Swaziland were selected as they participated in a SADC workshop during which the authors collected data. The study includes, in other words, nine of the fifteen member states of SADC (Figure 1).

Data are collected through focus groups and content analysis of documentary sources, as well as through interviews with key informants in Botswana and Tanzania, as a part of broader studies, and in Zambia and Zimbabwe. This combination of methods was chosen to attempt to cancel out the weaknesses of each method with the strengths of the others. Considering the research question, documentary sources are suitable as they most often have fast and cheap access to data (Hakim 1987:24; Kiecolt \& Nathan 1985:11-12), as well as having stable, unobtrusive and broad coverage (Yin 1994:80-82). However, blocked access (Yin 1994:8082), as well as inherent constraints, errors and bias (Hakim 1987:24; Kiecolt \& Nathan 1985:56-71; Yin 1994:80-82), may reduce their usefulness. To reduce these potential problems when studying documentary sources, focus groups may be conducted. Focus groups are considered to be a fast way to collect data from multiple respondents and may create a 'synergy' between the participants that makes the focus groups more productive (Belzile \& Öberg 2012:4). However, the group setting may create bias in the responses from each individual participant (Belzile \& Öberg 2012:4). Although the combination of the two is assumed to be a viable way to answer the research question, qualitative interviews are also conducted, in a few cases, to attain in-depth information that allows us to increase our understanding of the phenomenon under study (Trost 2005).

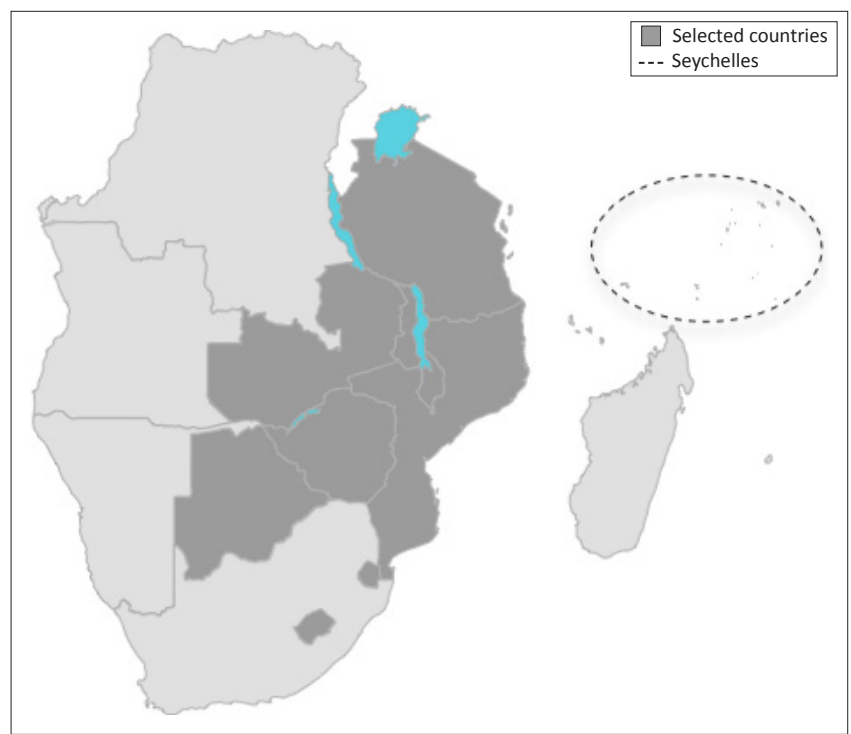

Source: Provided by Per Becker

FIGURE 1: The selected cases in the Southern African Development Community region.
The documentary sources include a mix of legislation, policies, position papers and descriptions of the current systems within the selected countries, which were collected on site or over the Internet. The study includes one regional focus group (18 participants), with participants from all selected countries except Tanzania, and one national focus group each in Zimbabwe (3 participants), Botswana (21 participants) and Tanzania (20 participants). The participants in the focus groups represent governmental ministries and departments, NGOs and international organisations. The study also includes qualitative interviews with key stakeholders (5 in Botswana, 5 in Tanzania and 1 in Zambia).

\section{Discussing the empirical findings}

In this section, the main results of the study are presented in terms of brief descriptions of the institutional setup regarding DRR as well as CCA in each of the studied countries (Table 1). The presentation is followed by discussions on the potential effects the current setup may have on efficiency when it comes to resource allocation for DRR and CCA, as well as an indication of areas in need of further research.

The collected data indicate that the responsibility for coordinating DRR and CCA activities resides with different stakeholders and coordination mechanisms in all studied countries except Mozambique, where the Instituto Nacional de Gestão de Calamidades (INGC, the National Disaster Management Institute), in addition to being the main body responsible for DRR, also has a shared responsibility for CCA with the Ministry for the Coordination of the Environment.

One could argue that the mere organisational setup for dealing with DRR and CCA respectively may not tell the whole story with regard to actual or potential coordination between these entities in a real life scenario. While this is a valid point, several of the interviewees representing stakeholders in DRR in Botswana and Tanzania (where more in-depth interviews were performed) indicated that not only were the parallel structures for dealing with DRR and CCA not reflected in the operational management of these concepts (i.e. little coordination took place between them), but that this situation is also perceived as problematic from a resource allocation perspective. In addition, when studying the National Adaptation Programme of Action (NAPA) on climate change available in most of the studied countries, we find very little evidence suggesting explicit coordination of DRR and CCA.

The purpose of this study is a purely descriptive one in terms of establishing to what extent parallel structures have in fact been established for DDR and CCA in the studied countries. More research is needed into the actual effects of these parallel structures on the overall efficiency of DRR and CCA in the SADC region, as well as of the situation in other parts of the world. In addition, future research with a 
TABLE 1: Brief descriptions of institutional setups for disaster risk reduction (DRR) and climate change adaptation (CCA) in the selected countries.

\begin{tabular}{ll}
\hline Country & Disaster Risk Reduction \\
\hline Botswana & $\begin{array}{l}\text { In Botswana the main responsibility for DRR rests with the National } \\
\text { Disaster Management Office (NDMO), under the Office of the } \\
\text { President. The main coordinating bodies at the national level are } \\
\text { the National Committee on Disaster Management (NCDM) and the } \\
\text { National Disaster Management Technical Committee (NDMTC). }\end{array}$ \\
Lesotho & $\begin{array}{l}\text { In Lesotho, the responsibility for DRR lies with the Disaster } \\
\text { Management System, under the Disaster Management Authority } \\
\text { (DMA), which falls under the Prime Minister's Office. }\end{array}$
\end{tabular}

Climate Change Adaptation

The main coordinating body for CCA in Botswana is the National Climate Change Committee (NCCC). This committee is administered under the Department of Meteorological Services, which falls under the Ministry of Environment, Wildlife and Tourism. Since 2010, there has been a National Climate Change Coordinator to increase climate change knowledge and skills within the Ministry of Environment, Wildlife and Climate char

Climate change adaptation is currently the responsibility of the Lesotho Meteorological Services, under the Ministry of Natural Resources, which coordinates the National Adaptation Programme of Action (NAPA) on climate change under the United Nations Framework Convention on Climate Change.

Malawi In Malawi, DRR is currently the responsibility of the Department of Disaster Management Affairs (DoDMA), under the Office of the President and Cabinet.

Mozambique In Mozambique, the main responsibility for DRR rests with Instituto Nacional de Gestão de Calamidades (INGC, National Disasters Management Institute), under the Ministry of State Administration.

The main responsibility regarding climate change rests with the Department of Climate Change and Meteorological Services, under the Ministry of Natural Resources, Energy and Environment.

Regarding CCA, the two main bodies are the Ministry for the Coordination of the Environment (MICOA) and Instituto Nacional de Gestão de Calamidades (INGC, National Disasters Management Institute), under the Ministry of State Administration. For example, MICOA is tasked with environmental policy coordination whilst INGC coordinates DRR (including Climate Risk Management). There seems to be some overlap in policy coordination between the two concerning CCA, which rightfully interfaces with the mandates of both institutions.

Seychelles In the Seychelles, DRR is currently the responsibility of the Department of Risk and Disaster Management, under the Office of the President.

The main responsible body for CCA is the Climate and Environmental Services Division (CESD), under the Department of Environment, which falls under the mandate of the Ministry of Environment, Natural Resources and Transport. There is also the Seychelles National Climate Change Committee (NCCC), which provides an overall co-ordination of the development and implementation of the national climate programme, and to act as an interface between the national climate programme and the government. Members of the committee include representatives from most government departments, the private sector and non-governmental organisations.

Swaziland In Swaziland, the main responsibility for DRR rests with the National Disaster Management Agency (NDMA), under the Deputy Prime Minister's Office.

Tanzania In Tanzania, the main responsibility for DRR lies with the Disaster Management Office, under the Office of the Prime Minister. The main coordinating body is the Tanzania Disaster Relief Committee (TANDREC) TANDREC is made up of Permanent Secretaries from Government Ministries or any other agencies determined by the Prime Minister as having a key role in disaster preparedness and response. The Permanent Secretary in the Office of the Prime Minister chairs the Committee.

Zambia In Zambia, the main responsible body for DRR is the Disaster Management and Mitigation Unit, under the Office of the Vice President.

Regarding CCA, the main responsible body is the Ministry of Tourism and Environmenta Affairs. A coordinating body has been established, namely the National Climate Change Committee, (NCCC), which was launched by the Minister for Tourism and Environmental Affairs with representatives from various ministries.

The main actors responsible for CCA are the Department of Environment (DoE), under the Vice President's Office (VPO), and the Tanzania Meteorological Agency (TMA). Ther is also a coordination function in place, namely the National Climate Change Steering Committee (NCCSC), which is an inter-ministerial committee comprising Permanent Secretaries (PS) from 13 ministries. The NCCSC reports to the Vice President's Office.

Although no specific legal and policy framework exists for CCA in Zambia, a number of existing government institutions and agencies have some mandates that have both explicit and implicit influence on issues relating to climate change. The Ministry of Tourism, Environment and Natural Resources (MTENR), for example, acts as the principal coordinating institution overseeing all activities relating to the environment which are implemented by sector departments, institutions and other agencies. And more recently (in 2009), the government of Zambia established the Zambia climate change facilitation unit (ZCCFU), which is located within the MTENR, with the principal responsibility of developing the climate change profile and adaptation policy for Zambia.

Zimbabwe In Zimbabwe, the main responsible body for DRR is the Department of Civil Protection, under the Ministry of Local Government, Rural and Urban Development, which falls under the office of the Vice President.

Regarding CCA, the main responsibility rests with the National Climate Change Office, under the Ministry Of Environment and Natural Resources Management. There is also a National Climate Change Committee consisting of a number of representatives from various ministries and governmental departments, together with representatives from industry and the environment research community.

critical and normative focus is needed in order to investigate the rationale for the creation of the different structures, their organisations, mandates and efficiency, as well as to explore potential ways in which to redesign these structures for more efficient DRR and CCA in the future.

\section{Conclusion}

The study shows that parallel structures for disaster risk reduction and climate change adaptation have been established in all but one of the studied countries. The qualitative interviews in Botswana and Tanzania indicated that stakeholders in disaster risk reduction view this duplication of structures as unfortunate, inefficient and a fertile setup for conflict over resources to implement similar activities. Additional research is needed to allow for the study of the rationale for and concrete effects of having these parallel structures as a foundation for advocacy and action for more efficient future disaster risk reduction and climate change adaptation in the SADC region.

\section{Acknowledgments Competing interests}

The authors declare that they have no financial or personal relationship(s) which may have inappropriately influenced them in writing this paper.

\section{Authors' contributions}

P.B. (Lund University) was responsible for project design. P.B. and M.A. (Lund University) performed the data collection. M.H. (Lund University) made conceptual contributions.

\section{References}

Arrhenius, P.S., 1896, 'On the influence of carbonic acid in the air upon the temperature of the ground', The London, Edinburgh, and Dublin Philosophical Magazine and Journal of Science 41(251), 237-276.

Belzile, J.A. \& Öberg, G., 2012, 'Where to begin? Grappling with how to use participant interaction in focus group design', Qualitative Research. http://dx.doi. participant interaction in focus group

Flyvbjerg, B., 2001, Making social science matter: why social inquiry fails and how it can succeed again, Cambridge University Press, Cambridge. http://dx.doi. org/10.1017/CBO9780511810503 
Greenwood, D. \& Levin, M., 2007, Introduction to Action Research: Social research for Social Change, 2nd edn, Sage Publications, Thousand Oaks.

Hakim, C., 1987, Research design: Strategies and choices in the design of social research, Allen and Unwin, London.

IDNDR, 1994, Yokohama Strategy and Plan of Action for a Safer World, Guidelines for Natural Disaster Prevention, Preparedness and Mitigation, International Strategy for Disaster Reduction, Geneva.

IPCC, 2007, IPCC Fourth Assessment Report: Climate Change 2007, Cambridge University Press, Cambridge and New York.

ISDR, 2004, Living with Risk: A global review of disaster reduction initiatives, United Nations, New York.

ISDR, 2005, Hyogo Framework for Action 2005-2015: Building the Resilience of Nations and Communities to Disasters, International Strategy for Disaster Reduction, Geneva.

Jeggle, T., 2001, 'The Evolution of Disaster Reduction as an International Strategy: Policy Implications for the Future', in U. Rosenthal, A. Boin \& L.K. Comfort (eds.), Managing Crises: Threats, Dilemmas, Opportunities, pp. 316-341, Charles C
Thomas, Springfield.

Kelman, I. \& Gaillard, J.C., 2008, 'Placing climate change within disaster risk reduction', Disaster Advances 1(3), 3-5.

Kiecolt, K.J. \& Nathan, L.E., 1985, Secondary analysis of survey data, Sage, London.

Mercer, J., 2010, 'Disaster risk reduction or climate change adaptation: Are we reinventing the wheel?', Journal of International Development 22(2), 247-264. http://dx.doi.org/10.1002/jid.1677
Mitchell, T. \& Van Aalst, M., 2008, Convergence of disaster risk reduction and climate change adaptation: A Review for DFID, DFID, London.

Satterthwaite, D., Huq, S., Pelling, M., Reid, H. \& Lankao, P.R., 2009, 'Adapting to Climate Change in Urban Areas: The Possibilities and Constraints in Lowand Middle-Income Nations,' in J. Bicknell, D. Dodman \& D. Satterthwaite (eds.), Adapting Cities to Climate Change: Understanding and Addressing the Development Challenges, pp. 3-47, Earthscan, London and Sterling.

Schipper, E.L.F., 2009, 'Meeting at the crossroads?: Exploring the linkages between climate change adaptation and disaster risk reduction', Climate and Development 1(1), 16-30. http://dx.doi.org/10.3763/cdev.2009.0004

Shea, E.L., 2003, 'Living with a climate in transition: Pacific communities plan for today and tomorrow', Asia Pac Issues 66, n.p.

Trost, J., 2005, Kvalitativa intervjuer, 2nd edn., Studentlitteratur, Lund.

Twigg, J., 2004, Disaster risk reduction: mitigation and preparedness in development and emergency programming, London: Overseas Development Institute, London.

UNISDR, 2009, UNISDR Terminology on Disaster Risk Reduction, United Nations, Geneva.

Vermaak, J. \& Van Niekerk, D., 2004, 'Disaster risk reduction initiatives in South Africa', Development Southern Africa 21(3), 555-574.

White, P., Pelling, M., Sen, K., Seddon, D., Russel, S. \& Few, R., 2004, Disaster risk reduction: a development concern, DFID, London.

Yin, R.K., 1994, Case Study Research: Design and Methods, 2nd edn., Thousand Oaks: Sage Publications. 